\title{
TO THE ANTHROPOLOGICAL TYPE OF THE SARMATIAN ELITE (BASED ON THE MATERIALS FROM BURIAL OF THE MIDDLE SARMATIAN TIME OF THE LOWER VOLGA REGION) ${ }^{1}$
}

\author{
Mariya A. Balabanova \\ Volgograd State University, Volgograd, Russian Federation
}

\begin{abstract}
This paper reviews the anthropological type of Sarmatian elite using craniological data which were obtained from the burials of the middle Sarmatian time. Elite complexes include burials where objects of material culture are represented with the symbols of power such as pectoral, torc, golden bracelets, silver and bronze cookware sets, clothes sheathed with gold plaques and so on. Reconstruction of a complex funeral rite, as well as grave goods, allow assuming that leaders of Sarmatian tribal unions were buried in such burials. Female elite burials are traditionally interpreted by archaeologists as burials of priestesses. The anthropological material, which is investigated in this paper, was obtained from the burials corresponding to the elite burial complexes in a varying degree and came from the burial mounds of the Volgograd and Astrakhan regions and the Republic of Kalmykia.

The series of 11 skulls ( 6 male and 5 female) was used for the study. Individual characteristics of skulls from the elite burials shows their significant morphological diversity. The series includes the skulls which can be characterized as both long-headed Europoid type and wide-headed Europoid type, which is often combined with moderate horizontal profiling.
\end{abstract}

Both series of different genders from the elite complexes differ in the direction of increasing massiveness as compared with the total average of Sarmatian series. Thus, comparing the male series, the arithmetic mean values of the elite group features demonstrate big massiveness, and standard deviations - a large intragroup variation.

As for the female series, although both compared groups are different, but there are fewer differences than at comparing the male series.

Key words: elite, stratigraphy of society, morphological type, funeral rite, individual characteristics, massive type.

Citation. Balabanova M.A., 2018. To the Anthropological Type of the Sarmatian Elite (Based on the Materials from Burial of the Middle Sarmatian Time of the Lower Volga Region). The Lower Volga Archaeological Bulletin, vol. 17, no. 2, pp. 32-50. (in Russian). DOI: https://doi.org/10.15688/nav.jvolsu.2018.2.3

УДК 930.26(470+571):393

Дата поступления статьи: 27.08.2018

ББК 63.48(2)-427.1

Дата принятия статьи: 23.10.2018

\section{К АНТРОПОЛОГИЧЕСКОМУ ТИПУ САРМАТСКОЙ ЭЛИТЫ (ПО МАТЕРИАЛАМ ПОГРЕБЕНИЙ СРЕДНЕСАРМАТСКОГО ВРЕМЕНИ НИЖНЕГО ПОВОЛЖЬЯ) ${ }^{1}$}

\section{Мария Афанасьевна Балабанова}

Волгоградский государственный университет, г. Волгоград, Российская Федерация

Аннотация. В данной статье рассматривается антропологический тип сарматской элиты по краниологическим данным, полученным из погребений среднесарматского времени. К элитным комплексам относят захоронения, в которых предметы материальной культуры представлены символами власти - пекторалью, гривной, а также браслетами из золота, серебряными и бронзовыми наборами посуды; одеждой, обшитой золотыми бляшками и др. Реконструкция сложного погребального обряда, а также вещевой комплекс позволяют предположить, что в таких погребениях хоронили предводителей сарматских племенных союзов. Женские элитные погребения 
всеми археологами интерпретируются как погребения жриц. Антропологический материал, который исследуется в данной статье, был получен из захоронений, в той или иной степени соответствующих элитным погребальным комплексам, и происходит из могильников Волгоградской и Астраханской областей и Калмыкии.

Для исследования использовалась серия, насчитывающая 11 черепов (6 мужских и 5 - женских). Индивидуальная характеристика черепов из элитных погребений показала их значительное морфологическое разнообразие. В серии присутствуют черепа, которые характеризуются как длинноголовым европеоидным типом, так и широкоголовым европеоидным типом, который зачастую сочетается с умеренной горизонтальной профилировкой.

Обе разнополые серии из элитных комплексов при сравнении с суммарной среднесарматской серией отличаются в сторону усиления массивности. Так, при сравнении мужских серий среднеарифметические значения признаков элитной группы демонстрируют большую массивность, а стандартные отклонения большую внутригрупповую вариацию.

Что касается женских серий, то хотя обе сравниваемые группы и отличаются между собой, но различий меньше, чем при сравнении мужских серий.

Ключевые слова: элита, стратиграфия общества, морфологический тип, погребальная обрядность, индивидуальная характеристика, массивный тип.

Цитирование. Балабанова М. А., 2018. К антропологическому типу сарматской элиты (по материалам погребений среднесарматского времени Нижнего Поволжья) // Нижневолжский археологический вестник. T. 17, № 2. C. 32-50. DOI: https://doi.org/10.15688/nav.jvolsu.2018.2.3

Введение. В современных археологических исследованиях приобретают популярность проблемы, связанные с реконструкциями социальной истории древних обществ. В таких работах авторы невольно уделяют особое внимание «элитным» погребальным комплексам. Раскопки таких памятников, несмотря на частые случаи их ограбления, позволяют получить представление о возможной социальной градации исследуемых обществ. Определение структуры элиты и особенностей организации высших слоев общества способствует уточнению уровня развития и специфики устройства рассматриваемого социума в целом. Данная проблема разрабатывается и при изучении материалов исследования комплексов среднесарматской культуры. Правда, до настоящего времени эта проблема еще не достаточно освещена. В основном имеются публикации ярких элитных курганов и погребений [Ковпаненко, 1986; Симоненко, Лобай, 1991; Дворниченко, Федоров-Давыдов, 1993; Беспалый, 1985; 1992; Прохорова, Гугуев, 1988; Скрипкин, Мыськов, 2009; Сергацков, 2009; Засецкая, 2011; Мордвинцева, 2013; Demkin et al., 2014 и др.]. Так как в элитных погребениях встречаются уникальные знаковые вещи - импортная посуда, конская упряжь, украшения, элементы парадного вооружения и др., то целая серия публикаций посвящена им [Клейн, 1979; Мордвинцева, 1994; Лукьяшко, 2000; Симоненко, 2002; 2011; Клепиков, 2013; Трейстер, 2016; Яценко, 2016 и др.].
Отдельная работа, посвященная элитным среднесарматским комплексам Нижнего Поволжья, позволила А.С. Скрипкину утверждать о том, что погребальная обрядность отражает различия в общественном положении погребенных под курганами [Скрипкин, 2017, с. 10]. К выделенным статусным признакам он относит «наиболее крупные насыпи, широкие прямоугольные ямы, наличие тайников, в качестве заупокойной пищи встречаются кости лошади и крупного рогатого скота; в материальной культуре - наличие вещей, изготовленных из золота (гривна, пектораль, браслеты, серьги, нашивные бляшки), серебряные кубки с зооморфной ручкой, чаши из серебра, стекла, алебастра, бронзовые котлы, клинковое оружие, колчаны со стрелами, детали конской упряжи» [Скрипкин, 2017, с. 11]. Особенности погребального обряда некоторых могил позволяют возводить погребенных в них людей в ранг «царей», предводителей племен и сарматских подразделений.

Имеется несколько работ, посвященных морфологическому облику среднесарматской элиты [Круц, 1991; Батиева, 2000; Перерва, 2012; Балабанова и др., 2014]. Чаще всего в них дается индивидуальная краниологическая характеристика черепов из элитных погребений. Более детально изучены два женских костяка из погребения 10 кургана Кобяково и из погребения 3 кургана 45 могильника Перегрузное I. Погребение из могильника Перегрузное I кроме эли- 
тарности погребального обряда и вещевого комплекса выделяет на общем фоне и практика посмертной трепанации черепа путем сверления [Батиева, 2000; Балабанова и др., 2014; Перерва, 2012; Demkin et al., 2014].

K сожалению, чаще всего элитные погребения среднесарматской культуры подвергаются ограблению, поэтому во многих из них отсутствует антропологический материал, но на протяжении нескольких десятилетий удалось собрать коллекцию черепов из погребений, атрибутированных археологами как элитные, что дает возможность рассмотреть антропологический тип сарматской элиты.

Материал исследования и его описание. Серия состоит из 11 черепов разной степени сохранности, и они все происходят из памятников среднесарматской археологической культуры Нижнего Поволжья. Часть из них была опубликована [Балабанова и др., 2014; Балабанова, Перерва, 2017]. Несмотря на это, в данной работе приводится более полная индивидуальная характеристика черепов и определение морфологических особенностей среднесарматской элиты [Алексеев, Дебец, 1964].

Индивидуальная характеристика черепов. Могильник Аксай II, курган 34, погребение 1 (табл. 1.8, рис. 1). Для исследования был представлен грацильный череп молодой женщины 20-25 лет хорошей сохранности [Балабанова, Перерва, 2017, с. 122, 123].

Мозговая коробка характеризуется средней длиной, средней шириной и большой высотой. По значениям указателей всех трех тотальных диаметров черепной коробки, череп мезокранный, гипсикранный и метриокранный. Ее вертикальная норма сфеноидная. Основание черепа короткое и средней ширины. Лоб среднеширокий по значению наименьшей ширины и широкий по значению наибольшей ширины. Угол поперечного изгиба лба слабый, а угол назион-метопион почти прямой. Лобная хорда и дуга средней длины, а теменная хорда и дуга длинные. Затылочная кость широкая с короткой хордой и средней длины дугой. Высота изгиба лба и затылка средняя.

Лицевой скелет мезоморфный с плоским назомалярным углом и резким зигомаксилярным, его вертикальный профиль - мезогнатный. Альвеолярная дуга и нёбо длинные и средней ширины. Нос тоже мезоморфный как по ширине и высоте, так и по указателю (мезоринный). Форма нижнего края грушевидного отверстия - предносовые ямки, передненосовая ость слабо выражена. Глазница узкая и средневысокая по высоте орбиты и высокая по указателю (гипсиконхная). Переносье узкое и средневысокое, а носовые кости средней ширины и высокие. Угол выступания носа большой. Клыковая ямка глубокая.

Могильник Аксай III, курган 3, погребение 1 [Балабанова, Перерва, 2017, с. 126, 127]. Череп принадлежал мужчине 35-45 лет (табл. 1.1; рис. 2). Мозговая коробка по тотальным размерам крупная: длинная, широкая и высокая; по указателям - долихокранная, ортокранная и метриокранная. Вертикальная норма черепа - эллипсоидная. Основание черепа длинное и широкое. Рельеф на черепе выражен максимально: надпереносье - 5 баллов; сосцевидные отростки - 3 балла; надбровные дуги - 2 балла; наружный затылочный бугор 5 баллов по Мартину. Лоб широкий и по значению наименьшей ширины и позначению наибольшей с резкой профилировкой в месте поперечного изгиба. Его хорда и дуга длинные. Теменная хорда длинная, а дуга средней длины. Затылочная кость широкая с длинной хордой и дугой. Высота изгиба лба средняя.

Лицевой скелет очень широкий по всем трем широтным размерам $(45 ; 43 ; 46$ размеры по Мартину). Его высота очень большая, горизонтальная профилировка резкая, а вертикальная профилировка - ортогнатная. Все части лицевого скелета также крупные и по мировой рубрикации соответствуют очень большим показателям [Алексеев, Дебец, 1964, с. 114]. Так, альвеолярная дуга и нёбо длинные и широкие; нос высокий и широкий как по абсолютным размерам, так и по указателю (платиринный), глазница широкая и средневысокая по высоте и низкая по указателю (хамеконхная). Форма нижнего края грушевидного отверстия - предносовые ямки. Переносье средней ширины и очень высокое, а носовые кости широкие и высокие. Угол выступания носа средний, а клыковая ямка глубокая.

Из аномалий на черепе зафиксированы двусоставные затылочные мыщелки и заднемыщелковые отверстия; теменные отверстия; подглазничный узор, тип II по А.Г. Козинцеву [Козинцев, 1988]; ореховидные вздутия на нижней 
челюсти. Кроме этого, наблюдались множественные костные остеомы на костях свода черепа размером не более 2-3 мм в диаметре.

Могильник Бердия, курган 3, погребение 1 (табл. 1.7). Череп хорошей сохранности принадлежал женщине старше 50 лет. Его мозговой отдел характеризуется большой длиной, средней шириной и малой высотой от базионбрегма. По пропорциям череп долихокранный, хамекранный и тапейнокранный. Лобная кость широкая в своей наименьшей части и узкая в наибольшей с резкой горизонтальной профилировкой в месте поперечного изгиба и наклонная по линии назион-метопион. Длина ее хорды большая, а дуги - средняя. Основание черепа длинное и широкое. Затылочная кость широкая с дугой и хордой средней длины. $\mathrm{У}$ теменной кости дуга и хорда длинные.

Лицевой отдел широкий по скуловому диаметру и средней высоты по верхней высоте с ослабленной горизонтальной профилировкой на уровне глазниц. Его вертикальная профилировка ортогнатная и по значениям общего лицевого угла, и по указателю выступания лица. Орбиты широкие и средневысокие, по указателю мезоконхные. Нос средней ширины и высокий с антропинной формой нижнего края грушевидного отверстия и лепторинным указателем. Переносье и носовые кости средней ширины и высокие. Нос резко выступающий к линии профиля. Клыковая ямка глубокая.

Могильник Ветютнев, курган 1, погребение 1 (табл. 1.5; рис. 3). Череп принадлежал мужчине, которому на момент смерти было около 30-35 лет. Его мозговая коробка длинная, средней ширины и с высоким сводом по ушной высоте (20-й признак по Мартину). По указателю череп попадает в категорию долихокранных форм. Его основание, а также лобная кость по наименьшей ширине узкие. По линии стефанион-стефанион (10-й размер по Мартину) лобная кость средней ширины, хорошо профилирована в поперечном изгибе и слегка наклонная по углу профиля лба назион-метопион. Лобная хорда и дуга длинные. Затылочная кость широкая с хордой и дугой средней длины. У теменной кости хорда и дуга короткие.

Лицевой скелет узкий и высокий с резкой горизонтальной и ортогнатной вертикальной профилировками. Нос высокий и узкий как по абсолютной ширине, так и по указателю (лепторинный). Орбита широкая и низкая, по указателю хамеконхная. Переносье узкое и высокое, а носовые кости широкие и высокие, средневыступающие к линии профиля. Клыковая ямка средней глубины.

Могильник Заханата, курган 8, погребение 2 (табл. 1.3). Череп принадлежал мужчине, которому на момент смерти было около 4050 лет. Череп хорошей сохранности и характеризуется длинной и широкой мозговой коробкой со средневысоким сводом от базион-брегма (17-й размер по Мартину) и высоким сводом от порион-порион (20-й размер по Мартину). По пропорциям тотальных размеров мозговой коробки череп мезокранный, хамекранный и тапейнокранный. Основание черепа средней длины и широкое. Лобная кость средней ширины по 9-му размеру и широкая по 10-му размеру. Угол поперечного изгиба лба резкий, а угол его профиля от назион метопион прямой. Лобная хорда и дуга длинные. Затылочная кость широкая с хордой и дугой средней длины. У теменной кости хорда длинная, а дуга средней длины.

Лицо широкое и высокое, умеренно профилированное в горизонтальной плоскости и ортогнатное в вертикальной. Нос средневысокий и широкий, по указателю тоже широкий платиринный. Глазница широкая и низкая как по 52-му размеру, так и по указателю (хамеконхная). Переносье узкое и высокое, а носовые кости широкие и высокие. Угол выступания носа большой, а клыковая ямка глубокая.

Могильник Никольское, курган 12, погребение 1 (табл. 1.2). Череп принадлежал мужчине преклонных лет. Лицевой скелет плохо сохранился. Мозговая коробка средней длины, очень широкая и с низким сводом. По пропорциям череп попадает в брахикранные, хамекранные и тапейнокранные формы. Его вертикальная норма сфероидная. Рельеф на черепе развит хорошо, особенно затылочная область и сосцевидные отростки. Ширина основания черепа, наименьшая ширина лба и ширина затылка тоже очень большие. Угол поперечного изгиба лба плоский, а его наибольшая ширина средняя. У лобной кости дуга и хорда длинные, у теменной кости хорда и дуга короткие, а у затылочной кости дуга длинная, а хорда средней длины. Затылочно-теменной индекс попадает в показатели, характеризующие монголоидные популяции $(102,5)$ [Беневоленская, 1980]. 
Лицо по верхней ширине широкое с ослабленной профилировкой на уровне глазниц. Нос средней ширины.

Могильник Перегрузное I, курган 45, погребение 3 (табл. 1.11; рис. 4). Череп женщины 25-30 лет. Сохранность черепа хорошая. Швы на черепе с внешней стороны частично облитерированы [Балабанова и др., 2014, с. 246-248].

Мозговой отдел характеризуется большим продольным диаметром, средними размерами поперечного и высотного диаметров. По пропорциям череп мезокранный, акрокранный и метриокранный. Лобная кость средней ширины с резкой горизонтальной профилировкой в месте поперечного изгиба и с прямой вертикальной профилировкой. Длина ее хорды и дуги большая. Основание черепа короткое и широкое. Затылочная кость широкая с длинной дугой и средней длины хордой. У теменной кости дуга и хорда средней длины.

Лицевой отдел крупный, широкий по скуловому диаметру и высокий по верхней высоте с ослабленной горизонтальной профилировкой, особенно на среднем уровне. Его вертикальная профилировка ортогнатная и по значениям общего лицевого угла, и по указателю выступания лица. Орбиты широкие и средневысокие, по указателю хамеконхные. Нос узкий и высокий с антропинной формой нижнего края грушевидного отверстия и лепторинным указателем. Носовые кости узкие, средневысокие, умеренно выступающие к линии профиля, а переносье узкое и высокое. Клыковая ямка глубокая.

Перегрузное I, курган 51, погребение 1 (табл. 1.6; рис. 5). Полный набор частично фрагментированных костей скелета принадлежал мужчине 35-45 лет [Балабанова и др., 2014, с. 246248]. В результате реставрационных работ удалось реконструировать мозговой отдел и частично лицевой. Мозговая коробка длинная, узкая и низкая, по пропорциям долихокранная, хамекранная и метриокранная. Вертикальная форма черепа овоидная. Рельеф на черепе сильно выражен, с шиньонообразной формой затылка. Основание черепа средней длины и широкое. Лобная кость среднеширокая, плоская в месте перегиба.

Лицо широкое, с низкой глазницей. Переносье и носовые кости широкие и высокие.

В области лямбдовидного шва обнаружены множественные дополнительные кости. В сагиттальном шве дополнительные кости, ло- кализующиеся в затылочной области. Родничковые кости зафиксированы в месте расположения антропологических точек «asterion».

Могильник Старица, курган 11, погребение 1 (табл. 1.9). Череп с сильной посмертной деформацией затылочной кости принадлежал женщине старческого возраста. Из-за посмертной деформации часть признаков искажена, поэтому в процессе исследования они не измерялись. Кривизна лобной кости сильно снижена, что свидетельствует о наличии искусственной деформации. Данное погребение М.В. Кривошеевым датируется серединой II в. н.э. и относится к раннему этапу позднесарматской культуры [Кривошеев, 2016, с. 126], хотя погребальный обряд сочетает черты позднесарматской и среднесарматской культур.

Череп средних размеров как по показателям тотальных размеров, так и по их пропорции. Лобная кость средней ширины и сильно уплощенная в своем поперечном изгибе, ее дуга средней длины, а хорда большой. У затылочной кости и ширина, и длина дуги средних размеров.

Лицевой скелет широкий по верхней ширине лица, высокий с умеренной горизонтальной профилировкой на верхнем уровне и резкой на среднем. Нос высокий и узкий, лепторинный по указателю с инфантильным строением нижнего края грушевидного отверстия. Орбиты широкие и высокие, а по указателю мезоконхные. Носовые кости широкие и очень высокие. Клыковая ямка мелкая.

МогильникЭвдык I, курган 4, погребение 18 (табл. 1.4). Череп хорошей сохранности принадлежал мужчине, на момент смерти которому было около 50 лет. Мозговая капсула средней длины и очень широкая. Высота ее свода средняя от базион-брегма и высокая от порион-порион. Указатели тотальных размеров мозговой коробки находятся в пределах брахикранных, ортокранных и тапейнокранных форм. Череп массивный с хорошо развитым рельефом. На затылке мощный затылочный гребень и очень длинные сосцевидные отростки. Основание короткое и широкое. Лоб широкий по обоим размерам (9-й и 10-й размер по Мартину), умеренно профилированный по линии фронто-темпоральных точек и почти с покатым вертикальным профилем. Лобная хорда длинная, а дуга средней длины. Затылочная хорда и дуга длинные, а теменная хорда и дуга средней длины. 
Лицевой скелет мезоморфный, слабо профилированный на уровне глазниц и резко на уровне зигомаксилярных точек. Его вертикальный профиль ортогнатный. Нос высокий и узкий с лепторинным указателем и антропинной формой нижнего края грушевидного отверстия. Глазница широкая и высокая, но по указателю мезоконхная. Переносье узкое и высокое, а носовые кости средней ширины и высокие. Угол выступания очень большой. Клыковая ямка средней глубины.

Характеристика среднего типа разнопольх групп среднесарматской элитьл. Мужская серия насчитывает 6 черепов разной степени сохранности (табл. 2). Серия характеризуется крупной черепной коробкой, длинной и широкой. Высота его свода средняя по высотному диаметру от базион-брегма (17-й размер) и большая по ушной высоте (20-й размер по Мартину). Соотношение продольного и поперечного диаметров дает указатель мезокранный, продольного и высотного - указатель ортокранный, а поперечного и высотного - тапейнокранный. Основание черепа длинное и широкое. Лоб также широкий, умеренно профилированный по линии наименьшей ширины и средненаклонный по вертикальному профилю.

Лицо среднеширокое и высокое с ортогнатной вертикальной профилировкой. Его горизонтальная профилировка умеренная на верхнем уровне и резкая на уровне скуловых костей. Нос среднеширокий и высокий, по указателю мезоринный с широкими и высокими резко выступающими носовыми костями. Орбиты широкие и средневысокие, хамеконхные. Переносье узкое и высокое. Клыковая ямка глубокая.

Женская группа насчитывает 5 черепов, часть из которых плохой сохранности (табл. 2). Мозговая коробка в этой группе сочетает средние размеры длины и ширины со средневысоким сводом от базион-брегма и высоким по ушной ширине. Пропорции тотальных размеров мозговой коробки попадают в категории мезобрахикранных, ортокранных и метриокранных величин. Основание черепа почти длинное и широкое, лобная кость среднеширокая, плоская и слегка наклонная.

Лицо крупное, широкое и высокое, умеренно профилированное на обеих горизонтальных уровнях и ортогнатное на вертикальном уровне. Нос высокий и среднеширокий и по абсолютной ширине и по указателю (мезоринный). Орбиты широкие и средневысокие по обоим параметрам (мезоконхные). Переносье узкое и высокое, а носовые кости среднеширокие и высокие. Нос сильно выступает к линии профиля. Клыковая ямка средней глубины.

Из вышеприведенной усредненной характеристики разнополых групп заметны различия в их морфологическом типе. Половой диморфизм направлен как на параметры мозговой коробки, так и на горизонтальную профилировку лицевого скелета, которая сильнее ослаблена в женской серии. Поэтому серия мужских черепов в большей степени диагностирует европеоидные качества, чем серия женских черепов.

Индивидуальная характеристика разнополых черепов из элитных комплексов среднесарматского времени показала их внутригрупповую неоднородность, но плохая сохранность черепов не позволяет проводить более детальный анализ.

Сравнение мужских серий из элитных погребальных комплексов с суммарной среднесарматской показало следующие результаты:

1) среднеарифметические значения признаков элитной группы демонстрируют большую массивность (рис. 6);

2) значения стандартных отклонений большую внутригрупповую вариацию элитной серии (рис. 7).

Что касается женских серий, то хотя обе сравниваемые группы и отличаются между собой, но различий меньше, чем при сравнении мужских серий (рис. 8, 9).

Заключение. Суммируя вышеизложенные результаты исследования, можно отметить, что мужская часть среднесарматской элиты обладала более массивным обликом, чем остальная часть общества. Этот результат исследования соотносится с аналогичным выводом, который многократно подтвержден при сравнении серий позднесарматского времени практиковавших и не практиковавших обычай искусственной деформации головы. Серия деформированных черепов массивнее, чем не деформированных. Как показывают исследования, этот обычай носил знаковый характер и мог символизировать элитность на фоне остальной части общества, не практикующего обычай. 
M.A. Balabanova. To the Anthropological Type of the Sarmatian Elite

Таблица 1

Индивидуальные значения и указатели краниометрических признаков

\begin{tabular}{|c|l|c|c|c|c|c|c|c|c|}
\hline $\begin{array}{c}\text { № } \\
\text { п/п }\end{array}$ & $\begin{array}{c}\text { Могильник/курган/ } \\
\text { погребение }\end{array}$ & Пол & $\begin{array}{c}\text { Возраст } \\
\text { (лет) }\end{array}$ & $\begin{array}{c}1 . \text { Про- } \\
\text { дольный } \\
\text { диаметр }\end{array}$ & $\begin{array}{c}8 . \text { Попе- } \\
\text { речный } \\
\text { диаметр }\end{array}$ & $\begin{array}{c}8: 1 . \text { Че- } \\
\text { репной } \\
\text { указа- } \\
\text { тель }\end{array}$ & $\begin{array}{c}17 . \text { Вы- } \\
\text { сотный } \\
\text { диаметр }\end{array}$ & $\begin{array}{c}17: 1 . \text { Вы- } \\
\text { сотно- } \\
\text { продоль- } \\
\text { ный ука- } \\
\text { затель }\end{array}$ & $\begin{array}{c}17: 8 . \text { Вы- } \\
\text { сотно- } \\
\text { попереч- } \\
\text { ный ука- } \\
\text { затель }\end{array}$ \\
\hline 1 & Аксай III-3/1 & мужчина & $35-45$ & 198 & 147 & 74,2 & 144 & 72,7 & 98 \\
\hline 2 & Никольское-12/1 & мужчина & ст. 50 & 181 & 163 & 90 & 124 & 68,5 & 76,1 \\
\hline 3 & Заханата-8/2 & мужчина & $45-55$ & 192 & 151 & 78,6 & 133 & 69,3 & 88,1 \\
\hline 4 & Эвдык I-4/18 & мужчина & $40-50$ & 182 & 154 & 84,4 & 136 & 74,7 & 88,3 \\
\hline 5 & Ветютнев-1/1 & мужчина & $30-35$ & 196 & 142 & 72,4 & & & \\
\hline 6 & Перегрузное I-51/1 & мужчина & $40-45$ & 191 & 135 & 70,7 & 131 & 68,6 & 97 \\
\hline 7 & Бердия-3/1 & женщина & ст. 50 & 182 & 136 & 74,7 & 125 & 68,7 & 91,9 \\
\hline 8 & Аксай-II-34/1 & женщина & $18-20$ & 171 & 144 & 84,2 & 133 & 77,8 & 92,4 \\
\hline 9 & Старица-11 & женщина & ст. 50 & 170 & 134 & 82 & - & - & - \\
\hline 10 & Перегрузное I, 51/2 * & женщина & $25-35$ & & & & & & \\
\hline 11 & Перегрузное-I-45-1 & женщина & $25-35$ & 176 & 136 & 77,3 & 127 & 72,2 & 93,4 \\
\hline
\end{tabular}

Примечание. * - из-за плохой сохранности в тексте не приводится индивидуальная характеристика данного черепа.

Продолжение таблиць 1

\begin{tabular}{|c|c|c|c|c|c|c|c|c|c|c|}
\hline $\begin{array}{c}\text { № } \\
\text { п/п }\end{array}$ & $\begin{array}{c}\text { 5. Длина } \\
\text { основа- } \\
\text { ния чере- } \\
\text { па }\end{array}$ & $\begin{array}{c}\text { 20. УШая высо- } \\
\text { та }\end{array}$ & $\begin{array}{c}\text { 9. Наи- } \\
\text { меньшая } \\
\text { ширина } \\
\text { лба }\end{array}$ & $\begin{array}{c}\text { УПИЛ. } \\
\text { Угол по- } \\
\text { перечно- } \\
\text { го изгиба } \\
\text { лба }\end{array}$ & $\begin{array}{c}\text { 9:8. Лоб- } \\
\text { но- } \\
\text { попереч- } \\
\text { ный ука- } \\
\text { затель }\end{array}$ & $\begin{array}{c}\text { 9:10. } \\
\text { Широт- } \\
\text { ный лоб- } \\
\text { ный ука- } \\
\text { затель }\end{array}$ & $\begin{array}{c}\text { 10. Наи- } \\
\text { большая } \\
\text { ширина } \\
\text { лба }\end{array}$ & $\begin{array}{c}\text { 11. Ши- } \\
\text { рина ос- } \\
\text { нования } \\
\text { черепа }\end{array}$ & $\begin{array}{c}12 . \text { Ши- } \\
\text { рина за- } \\
\text { тылка }\end{array}$ & $\begin{array}{c}28: 27 . \\
\text { Затылоч- } \\
\text { но- } \\
\text { теменной } \\
\text { указатель }\end{array}$ \\
\hline 1 & 114 & 121 & 108 & 136 & 73,5 & 86,4 & 125 & 139 & 125 & 106,9 \\
\hline 2 & & & 103 & 141,4 & 63,2 & 85,8 & 120 & 155 & 128 & 102,5 \\
\hline 3 & 102 & 123 & 97 & 132,3 & 64,2 & 77,0 & 126 & 134 & 120 & 91,5 \\
\hline 4 & 98 & 117 & 101 & 140,8 & 65,6 & 78,9 & 128 & 128 & - & 97,5 \\
\hline 5 & & 119,5 & 92 & 136,2 & 64,8 & 78,6 & 117 & 121 & 115 & 81 \\
\hline 6 & 104 & & 95 & 143,9 & 70,4 & 79,8 & 119 & 131 & 119 & 110,7 \\
\hline 7 & 102 & 114 & 101 & 131,9 & 74,3 & 91,0 & 111 & 129 & 111 & 86,9 \\
\hline 8 & 92 & 114 & 91 & 141,6 & 63,2 & 78,4 & 116 & 121 & 109 & 82,3 \\
\hline 9 & - & - & 92 & 152,6 & 68,7 & 81,4 & 113 & - & 105 & 89 \\
\hline 10 & & & & & & & & 115 & 104 & \\
\hline 11 & 93 & 114,5 & 93 & 135,8 & 68,4 & 88,6 & 105 & 125 & 108 & 95,2 \\
\hline
\end{tabular}

Продолжение таблищы 1

\begin{tabular}{|c|c|c|c|c|c|c|c|c|c|c|}
\hline $\begin{array}{c}\text { № } \\
\text { п/п }\end{array}$ & $\begin{array}{c}25 . \text { Саги- } \\
\text { тальная } \\
\text { дуга }\end{array}$ & $\begin{array}{c}\text { 26. Лоб- } \\
\text { ная дуга }\end{array}$ & $\begin{array}{c}27 . \text { Те- } \\
\text { менная } \\
\text { дуга }\end{array}$ & $\begin{array}{c}28 . \text { Заты- } \\
\text { лочная } \\
\text { дуга }\end{array}$ & $\begin{array}{c}\text { 29. Лоб- } \\
\text { ная хорда }\end{array}$ & $\begin{array}{c}30 . \text { Те- } \\
\text { менная } \\
\text { хорда }\end{array}$ & $\begin{array}{c}31 . \text { Заты- } \\
\text { лочная } \\
\text { хорда }\end{array}$ & $\begin{array}{c}29: 26 . \\
\text { Изгиб } \\
\text { лба }\end{array}$ & $\begin{array}{c}30: 27 . \\
\text { Изгиб } \\
\text { темени }\end{array}$ & $\begin{array}{c}31: 28 . \\
\text { Изгиб } \\
\text { затылка }\end{array}$ \\
\hline 1 & 404 & 135 & 130 & 139 & 118 & 118 & 106 & 87,4 & 90,8 & 76,3 \\
\hline 2 & 380 & 137 & 120 & 123 & 120 & 107 & 99 & 87,6 & 89,2 & 80,5 \\
\hline 3 & 384 & 137 & 129 & 118 & 119 & 117 & 95 & 86,9 & 90,7 & 80,5 \\
\hline 4 & 371 & 130 & 122 & 119 & 115 & 111 & 101 & 88,5 & 91,0 & 84,9 \\
\hline 5 & 390 & 130 & 139 & 121 & 115 & 115 & 96 & 88,5 & 82,7 & 79,3 \\
\hline 6 & 375 & 118 & 122 & 135 & 104 & 111 & 99 & 84,9 & 88,6 & 80,3 \\
\hline 7 & 364 & 121 & 130 & 113 & 110 & 117 & 91 & 90,9 & 90 & 80,5 \\
\hline 8 & 360 & 123 & 130 & 107 & 108 & 115 & 87 & 87,8 & 88,5 & 81,3 \\
\hline 9 & & 124 & 127 & 113 & 115 & 111 & & 92,7 & 87,4 & \\
\hline 10 & & & & 106 & & & 90 & & & \\
\hline 11 & 380 & 136 & 125 & 119 & 110 & 109 & 94 & 80,9 & 87,2 & 79,0 \\
\hline
\end{tabular}


Продолжение таблицы 1

\begin{tabular}{|c|c|c|c|c|c|c|c|c|c|c|}
\hline $\begin{array}{c}\text { № } \\
\Pi / \Pi\end{array}$ & $\begin{array}{c}\text { 45. Ску- } \\
\text { ловой } \\
\text { диаметр }\end{array}$ & $\begin{array}{c}\text { 45:8. По- } \\
\text { перечный } \\
\text { фацио- } \\
\text { цереб- } \\
\text { ральный } \\
\text { указатель }\end{array}$ & $\begin{array}{c}\text { 40. Длина } \\
\text { основа- } \\
\text { ния лица }\end{array}$ & $\begin{array}{c}40: 5 . \\
\text { Указа- } \\
\text { тель вы- } \\
\text { ступания } \\
\text { лица }\end{array}$ & $\begin{array}{c}\text { 48. Верх- } \\
\text { няя вы- } \\
\text { сота лица }\end{array}$ & $\begin{array}{c}48: 17 . \\
\text { Верти- } \\
\text { кальный } \\
\text { фацио- } \\
\text { цереб- } \\
\text { ральный } \\
\text { указатель }\end{array}$ & $\begin{array}{c}48: 45 . \\
\text { Верхний } \\
\text { лицевой } \\
\text { указатель }\end{array}$ & $\begin{array}{l}\text { 43. Верх- } \\
\text { няя ши- } \\
\text { рина ли- } \\
\text { ца }\end{array}$ & $\begin{array}{l}\text { 46. Сред- } \\
\text { няя ши- } \\
\text { рина ли- } \\
\text { ца }\end{array}$ & $\begin{array}{c}\text { 54. Ши- } \\
\text { рина носа }\end{array}$ \\
\hline 1 & 144 & 98,0 & 108 & 94,7 & 82 & 56,9 & 56,9 & 118 & 106 & 30 \\
\hline 2 & & & & & & & & 114 & & 25 \\
\hline 3 & 141 & 93,4 & 102 & 100 & 74 & 55,6 & 52,5 & 109 & 96 & 27 \\
\hline 4 & 135 & 87,7 & 93 & 96 & 71 & 52,2 & 52,6 & 108 & 90 & 24 \\
\hline 5 & 125 & 88,0 & & & 79 & & 63,2 & 102 & 92 & 24 \\
\hline 6 & 137 & 101,5 & 88,1 & 91 & 73,3 & 54,8 & 53,5 & 108 & & \\
\hline 7 & 130 & 95,6 & 92 & 90,2 & 67 & 53,6 & 51,5 & 108 & & 23,5 \\
\hline 8 & 126 & 87,5 & 94 & 102,7 & 67,5 & 50,8 & 53,6 & 101 & 93 & 25 \\
\hline 9 & - & - & - & & 73 & & - & 105 & 91 & 23 \\
\hline 10 & & & & & & & & & & \\
\hline 11 & 130 & 95,6 & 90 & 96,8 & 71 & 55,9 & 54,6 & 108 & 99 & 23 \\
\hline
\end{tabular}

Продолжение таблицьы 1

\begin{tabular}{|c|c|c|c|c|c|c|c|c|c|c|}
\hline $\begin{array}{l}\text { № } \\
\text { п/п }\end{array}$ & $\begin{array}{c}55 . \text { Высо- } \\
\text { та носа }\end{array}$ & $\begin{array}{c}54: 55 . \\
\text { Носовой } \\
\text { указатель }\end{array}$ & $\begin{array}{c}51 . \text { Шин- } \\
\text { рина ор- } \\
\text { биты }\end{array}$ & $\begin{array}{c}52 \text {. Высо- } \\
\text { та орби- } \\
\text { ты }\end{array}$ & $\begin{array}{c}52: 51 . \\
\text { Орбит- } \\
\text { ный ука- } \\
\text { затель }\end{array}$ & $\begin{array}{c}\text { МС. } \\
\text { Максило- } \\
\text { фрон- } \\
\text { тальная } \\
\text { ширина }\end{array}$ & $\begin{array}{c}\text { МS. } \\
\text { Максило- } \\
\text { фрон- } \\
\text { тальная } \\
\text { высота }\end{array}$ & $\begin{array}{c}\text { МS:МС. } \\
\text { Максило- } \\
\text { фрон- } \\
\text { тальный } \\
\text { указатель }\end{array}$ & $\begin{array}{c}\text { DC. Дак- } \\
\text { риальная } \\
\text { ширина }\end{array}$ & $\begin{array}{c}\text { DS. Дак- } \\
\text { риальная } \\
\text { высота }\end{array}$ \\
\hline 1 & 56,5 & 53,1 & 48 & 34 & 70,8 & 20,5 & 9,2 & 44,9 & 22,4 & 13,4 \\
\hline 2 & & & & & & & & & & \\
\hline 3 & 52 & 51,9 & 44 & 33 & 75 & 18,5 & 8,6 & 46,5 & 18,9 & 13,1 \\
\hline 4 & 54 & 44,4 & 45 & 36 & 80 & 15,7 & 8,8 & 56,1 & 18,8 & 12,5 \\
\hline 5 & 55 & 43,6 & 43 & 32 & 74,4 & 20,5 & 11,5 & 56,1 & 20 & 12,5 \\
\hline 6 & & & & 31 & & 23,1 & 9 & 39 & & \\
\hline 7 & 52 & 45,2 & 44 & 34 & 77,3 & 19,5 & 11 & 56,4 & 19,5 & 15,2 \\
\hline 8 & 50 & 50 & 39 & 34,5 & 88,5 & 18,9 & 7,2 & 38,1 & 19,2 & 10,4 \\
\hline 9 & 53 & 43,4 & 43 & 36 & 83,7 & 19,5 & 8,3 & 42,6 & - & - \\
\hline 10 & & & & & & & & & & \\
\hline 11 & 51 & 45,1 & 45 & 34 & 75,6 & 17,5 & 6,2 & 35,4 & 19,2 & 11,5 \\
\hline
\end{tabular}

\section{Продолжение таблицы 1}

\begin{tabular}{|c|c|c|c|c|c|c|c|c|c|c|}
\hline $\begin{array}{l}\text { № } \\
\text { п/п }\end{array}$ & $\begin{array}{c}\text { DS:D. } \\
\text { Дакри- } \\
\text { альный } \\
\text { указатель }\end{array}$ & $\begin{array}{c}\text { SC. Си- } \\
\text { мотиче- } \\
\text { ская ши- } \\
\text { рина }\end{array}$ & $\begin{array}{c}\text { SS. Си- } \\
\text { мотиче- } \\
\text { ская вы- } \\
\text { сота }\end{array}$ & $\begin{array}{c}\text { SS:SC. } \\
\text { Сисоти- } \\
\text { ческий } \\
\text { указатель }\end{array}$ & $\begin{array}{c}\text { FС. Глу- } \\
\text { бина } \\
\text { клыковой } \\
\text { ямки }\end{array}$ & $\begin{array}{c}77 . \text { Назо- } \\
\text { маляр- } \\
\text { ный угол }\end{array}$ & $\begin{array}{c}\text { <zm'. Зи- } \\
\text { гомакси- } \\
\text { лярный } \\
\text { угол }\end{array}$ & $\begin{array}{c}\text { 32. Угол } \\
\text { профиля } \\
\text { лба от } \\
\text { назиона }\end{array}$ & $\begin{array}{c}72 . \text { Об- } \\
\text { щий ли- } \\
\text { цевой } \\
\text { угол }\end{array}$ & $\begin{array}{c}73 . \text { Угол } \\
\text { альвео- } \\
\text { лярной } \\
\text { части } \\
\text { лица }\end{array}$ \\
\hline 1 & 59,8 & 10,8 & 5,1 & 47,2 & 7,3 & 138,6 & 119,3 & 80 & 90 & 85 \\
\hline 2 & & & & & & 141 & & & & \\
\hline 3 & 69,3 & 9,8 & 5,4 & 55,1 & 7,3 & 141,8 & 130,2 & 88 & 91 & 77 \\
\hline 4 & 66,5 & 9,5 & 7 & 73,7 & 5 & 149,4 & 128 & 80 & 86 & 70 \\
\hline 5 & 62,5 & 12 & 7 & 58,3 & 5,5 & 133,1 & 122,2 & 84 & 88 & 75 \\
\hline 6 & & 12 & 4,5 & 37,5 & & & & & & \\
\hline 7 & 77,9 & 8,6 & 7,5 & 87,2 & & 143,1 & & 82 & 93 & 85 \\
\hline 8 & 54,2 & 9,2 & 4,1 & 44,6 & 5,5 & 145,3 & 127,1 & 88 & 82 & 69 \\
\hline 9 & - & 10 & 6 & 60 & 3,2 & 140,6 & 124,3 & - & - & - \\
\hline 10 & & & & & & & & & & \\
\hline 11 & 59,9 & 5,5 & 3,3 & 60 & 5,5 & 142 & 140,4 & 89 & 89 & 77 \\
\hline
\end{tabular}


Окончание таблицы 1

\begin{tabular}{|c|c|c|c|c|c|c|c|c|}
\hline $\begin{array}{l}\text { № } \\
\text { п/п }\end{array}$ & $\begin{array}{c}75-1 . \\
\text { Угол вы- } \\
\text { ступания } \\
\text { носа }\end{array}$ & $\begin{array}{c}\text { Форма че- } \\
\text { репа сверху }\end{array}$ & $\begin{array}{c}\text { Надпере- } \\
\text { носье }\end{array}$ & $\begin{array}{c}\text { Надбров- } \\
\text { ные дуги }\end{array}$ & $\begin{array}{c}\text { Наруж- } \\
\text { ный заты- } \\
\text { лочный } \\
\text { бугор }\end{array}$ & $\begin{array}{c}\text { Сосце- } \\
\text { видный } \\
\text { отросток }\end{array}$ & $\begin{array}{c}\text { Нижний край } \\
\text { грушевидно- } \\
\text { го отверстия }\end{array}$ & $\begin{array}{c}\text { Передне- } \\
\text { носовая } \\
\text { ость }\end{array}$ \\
\hline 1 & 28 & Ellips. & 5 & 2 & 5 & 3 & Fossa praen. & 5 \\
\hline 2 & & Sphaeroid. & 4 & 3 & 5 & 3 & Anthr & 3 \\
\hline 3 & 30 & Ellips & 4 & 3 & 4 & 3 & Anthr. & 4 \\
\hline 4 & 35 & Sphaeroid. & 4 & 2,5 & 5 & 3 & Anthr. & 4 \\
\hline 5 & 28 & Ellips. & 5 & 2 & 3 & 3 & Anthr. & 1 \\
\hline 6 & & Ovoid. & 4 & 2 & 4 & 2 & & \\
\hline 7 & 37 & & & & & & & \\
\hline 8 & 27 & Spaenoid. & 3 & 1 & 1 & 2 & Fossa praen. & 2 \\
\hline 9 & - & Spaenoid. & 3 & 2 & 2 & 2 & Ihfant. & \\
\hline 10 & & & & & 3 & 2 & Anthr & \\
\hline 11 & 24 & Pentagon. & 3 & 1 & 4 & 1 & Anthr & \\
\hline
\end{tabular}

Таблииа 2

Средние значения и указатели разнополых краниологических серий из элитных комплексов среднесарматской культуры

\begin{tabular}{|c|c|c|c|c|c|c|}
\hline \multirow{2}{*}{ № по } & \multicolumn{3}{|c|}{ Мужчины } & \multicolumn{3}{|c|}{ Женщины } \\
\cline { 2 - 7 } Мартину и др. & $n$ & $X$ & $s$ & $n$ & $X$ & $s$ \\
\hline 1 & 6 & 190,0 & 7,1 & 4 & 174,8 & 5,52 \\
\hline 8 & 6 & 148,7 & 9,7 & 4 & 137,5 & 4,4 \\
\hline $8: 1$ & 6 & 78,4 & 7,5 & 4 & 79,5 & 4,3 \\
\hline 17 & 5 & 133,6 & 7,3 & 3 & 128,3 & 4,2 \\
\hline $17: 1$ & 5 & 70,8 & 2,8 & 3 & 72,9 & 4,6 \\
\hline $17: 8$ & 5 & 89,5 & 8,8 & 3 & 92,6 & 0,8 \\
\hline 5 & 4 & 104,5 & 6,8 & 3 & 95,7 & 5,5 \\
\hline 20 & 4 & 120,1 & 2,5 & 3 & 114,2 & 0,3 \\
\hline 9 & 6 & 99,3 & 5,8 & 4 & 94,25 & 4,6 \\
\hline УПИЛ & 6 & 138,4 & 4,3 & 4 & 140,5 & 9,0 \\
\hline 11 & 6 & 134,7 & 11,6 & 4 & 122,5 & 6,0 \\
\hline $28: 27$ & 6 & 98,4 & 10,9 & 4 & 88,4 & 5,4 \\
\hline 45 & 5 & 136,4 & 7,3 & 3 & 128,7 & 2,3 \\
\hline 40 & 4 & 97,8 & 8,9 & 3 & 92,0 & 2,0 \\
\hline $40: 5$ & 4 & 95,4 & 3,7 & 3 & 96,6 & 6,2 \\
\hline 48 & 5 & 75,9 & 4,5 & 4 & 69,6 & 2,9 \\
\hline 43 & 6 & 109,8 & 5,5 & 4 & 105,5 & 3,3 \\
\hline 46 & 4 & 96,0 & 7,1 & 3 & 94,3 & 4,1 \\
\hline 54 & 5 & 26,0 & 2,5 & 4 & 23,6 & 0,9 \\
\hline 55 & 4 & 54,4 & 1,9 & 4 & 51,5 & 1,3 \\
\hline $54: 55$ & 4 & 48,25 & 4,9 & 4 & 45,9 & 2,8 \\
\hline 51 & 4 & 45,0 & 2,2 & 4 & 42,8 & 2,6 \\
\hline 52 & 5 & 33,2 & 1,9 & 4 & 34,6 & 0,9 \\
\hline $52: 51$ & 4 & 75,05 & 3,8 & 4 & 81,3 & 5,9 \\
\hline DC & 4 & 20,0 & 1,7 & 3 & 19,3 & 0,2 \\
\hline DS & 4 & 12,9 & 0,45 & 3 & 12,4 & 2,5 \\
\hline DS:DC & 4 & 64,5 & 4,2 & 3 & 64,0 & 12,4 \\
\hline SC & 5 & 10,8 & 1,2 & 4 & 8,3 & 2,0 \\
\hline SS & 5 & 5,8 & 1,1 & 4 & 5,2 & 1,9 \\
\hline SS:SC & 5 & 54,4 & 13,5 & 4 & 63,0 & 17,7 \\
\hline FC & 4 & 6,3 & 1,2 & 3 & 4,7 & 1,3 \\
\hline 77 & 5 & 140,8 & 5,9 & 4 & 142,8 & 2,0 \\
\hline$<$ zm & 4 & 124,9 & 5,0 & 3 & 130,6 & 8,6 \\
\hline 32 & 4 & 83,0 & 3,8 & 3 & 86,3 & 3,8 \\
\hline 72 & 4 & 88,8 & 2,2 & 3 & 88,0 & 5,6 \\
\hline 74 & 4 & 75,8 & 6,2 & 3 & 77,0 & 8,0 \\
\hline $75-1$ & 4 & 30,25 & 3,3 & 3 & 29,3 & 6,8 \\
\hline & & & & & \\
\hline
\end{tabular}




\section{ИЛЛЮСТРАЦИИ}
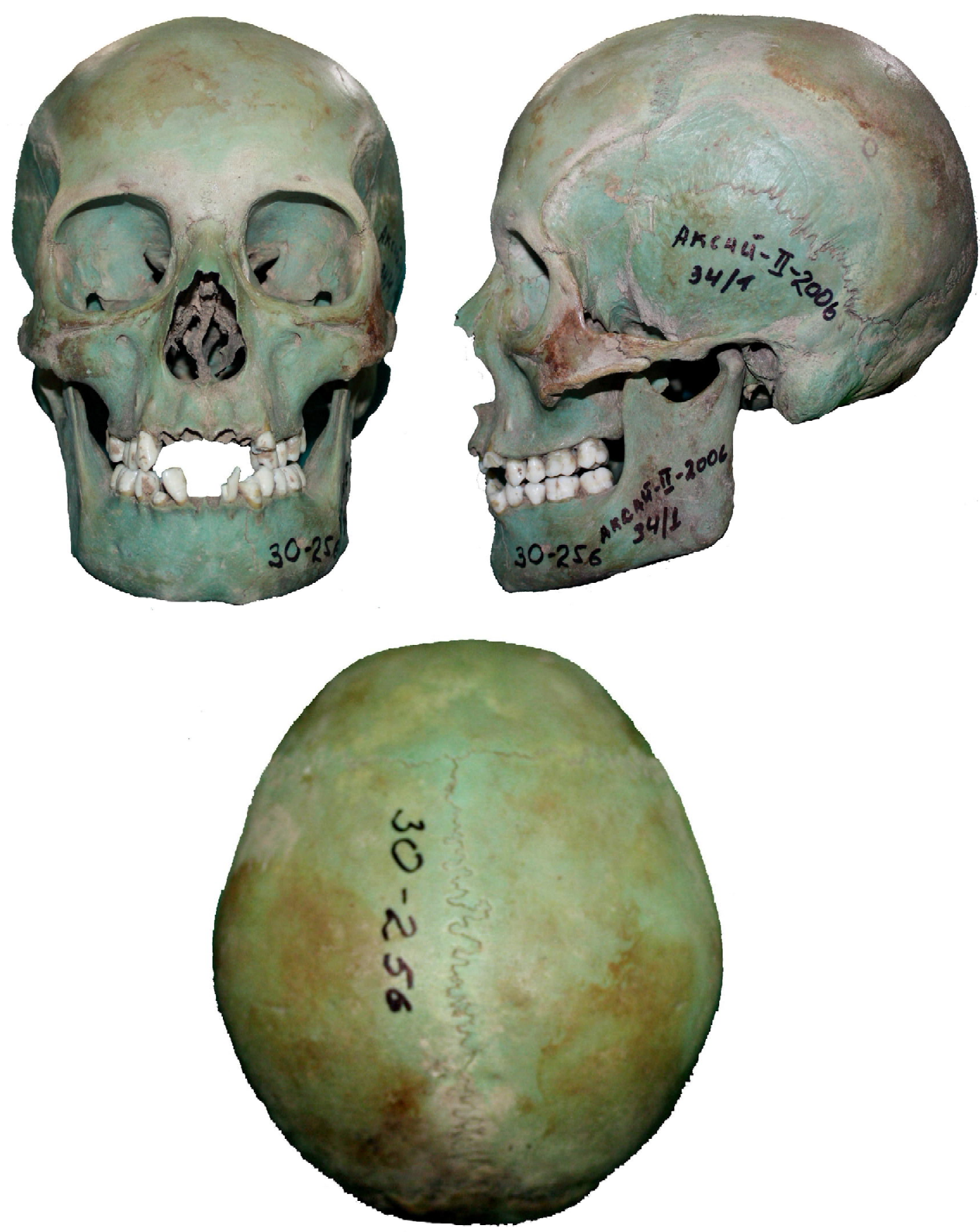

Рис. 1. Череп женщины (18-20 лет) из погребения 1 кургана 34 могильника Аксай II

Fig. 1. Female skull (18-20 years old) from burial 1 of barrow 34 (Aksai II burial mound) 
M.A. Balabanova. To the Anthropological Type of the Sarmatian Elite
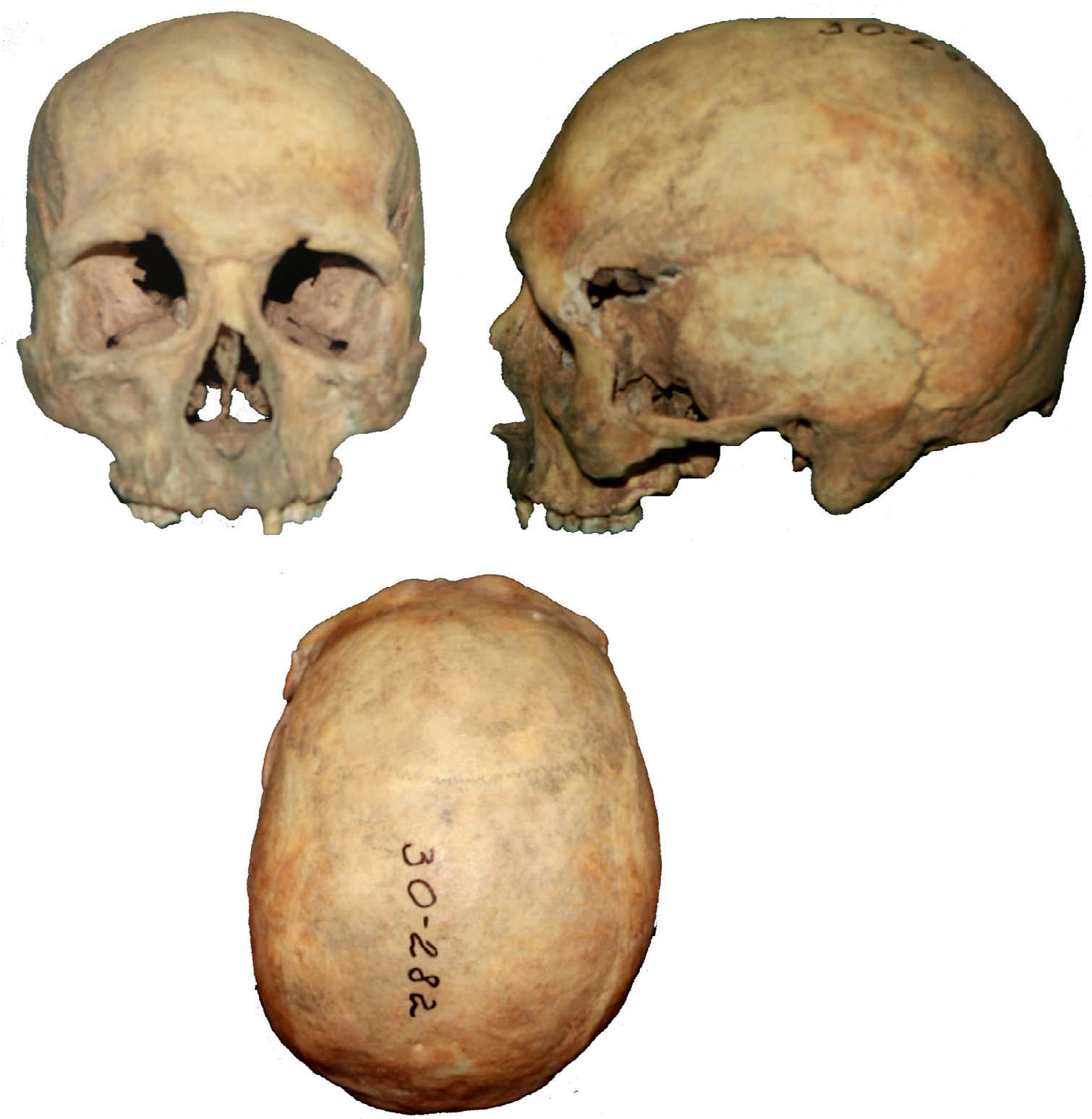

Рис. 2. Череп мужчины (35-45 лет) из погребения 1 кургана 3 могильника Аксай III

Fig. 2. Male skull (35-45 years old) from burial 1 of barrow 3 (Aksai III burial mound) 

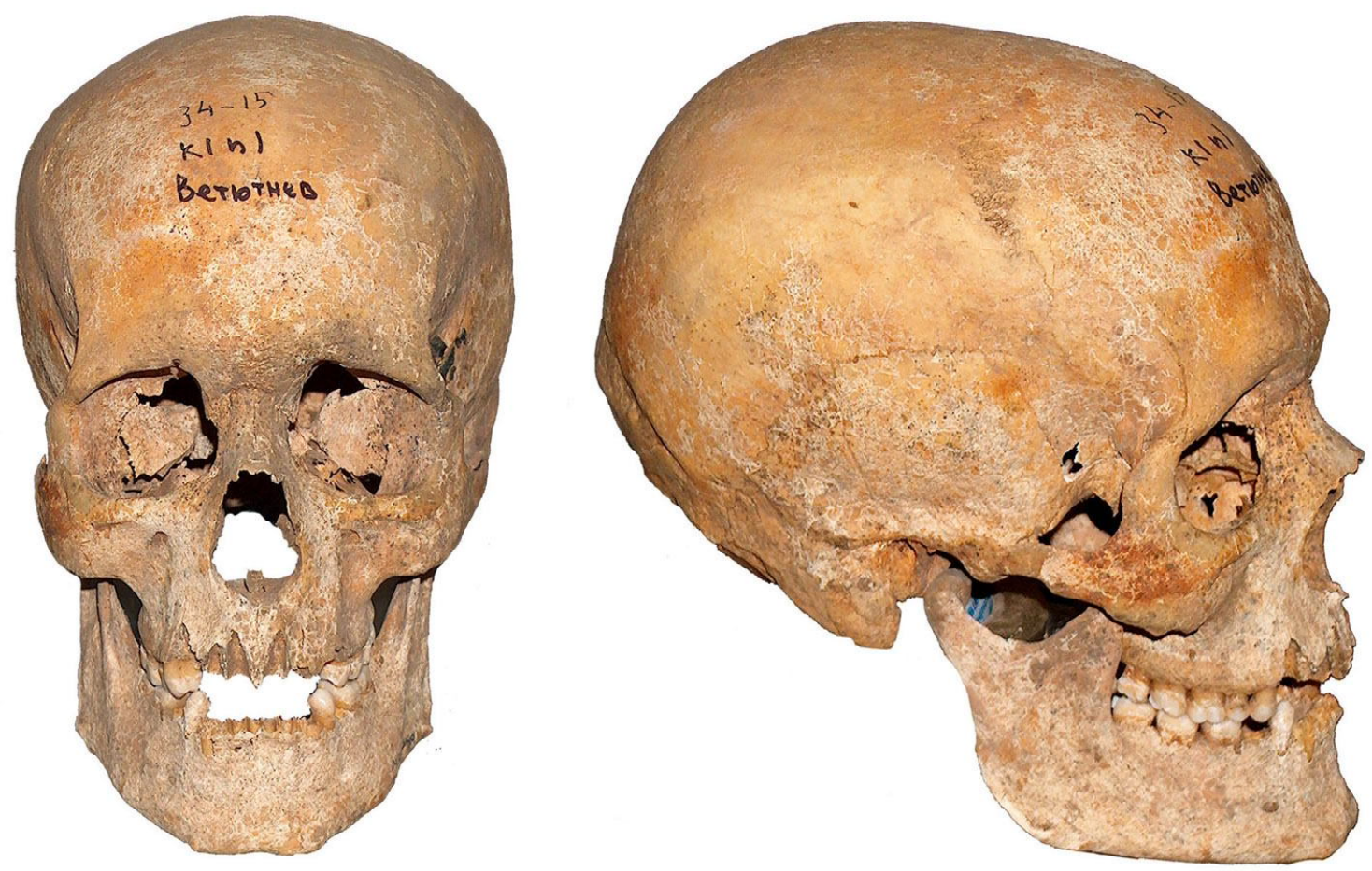

Рис. 3. Череп мужчины (30-35 лет) из погребения 1 кургана 1 могильника Ветютнев

Fig. 3. Male skull (30-35 years old) from burial 1 of barrow 1 (Vetyutnev burial mound) 
M.A. Balabanova. To the Anthropological Type of the Sarmatian Elite
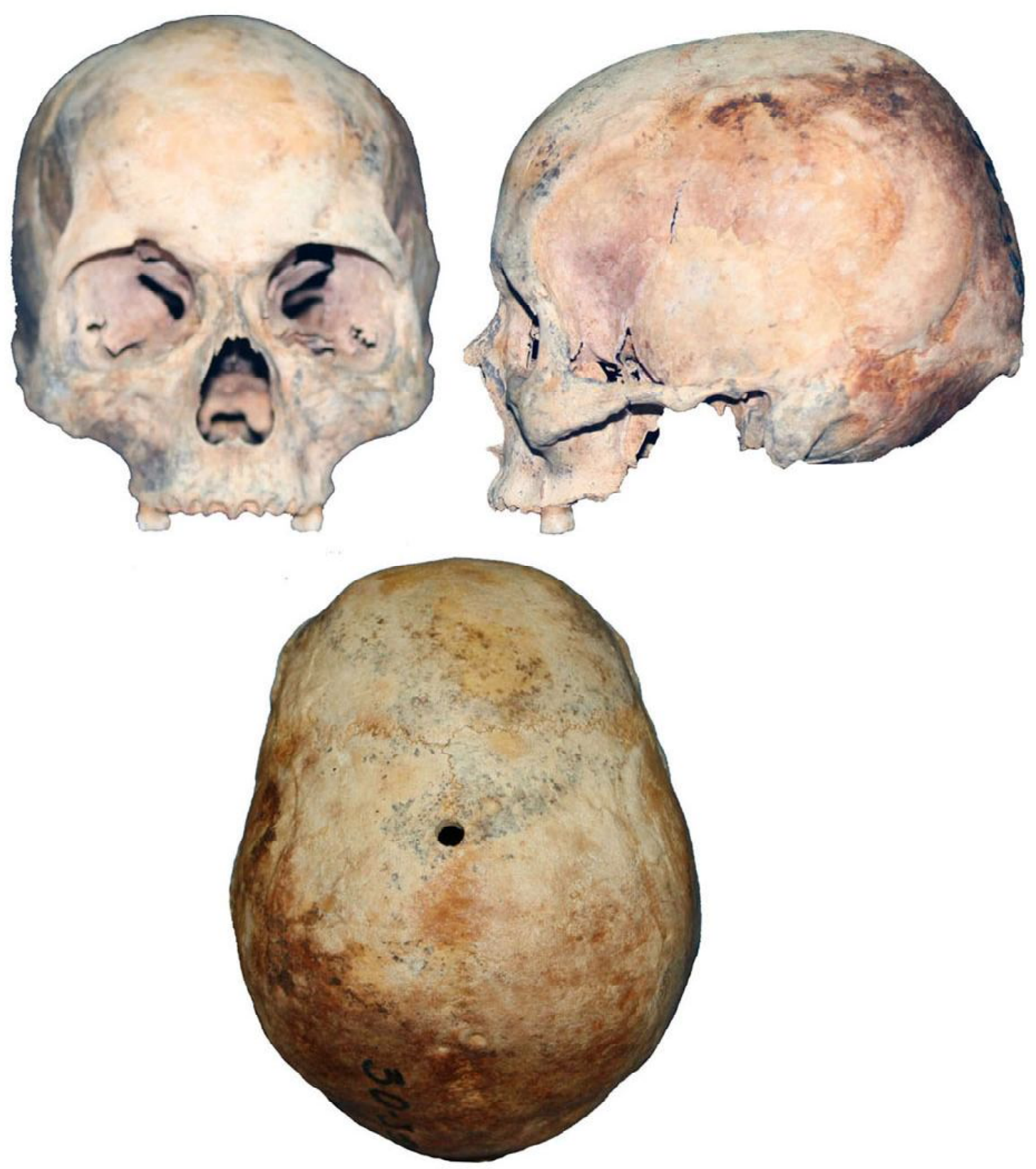

Рис. 4. Череп женщины (25-27 лет) из погребения 3 кургана 45 могильника Перегрузное I

Fig. 4. Female skull (25-27 years old) from burial 3 of barrow 45 (Peregruznoe I burial mound) 

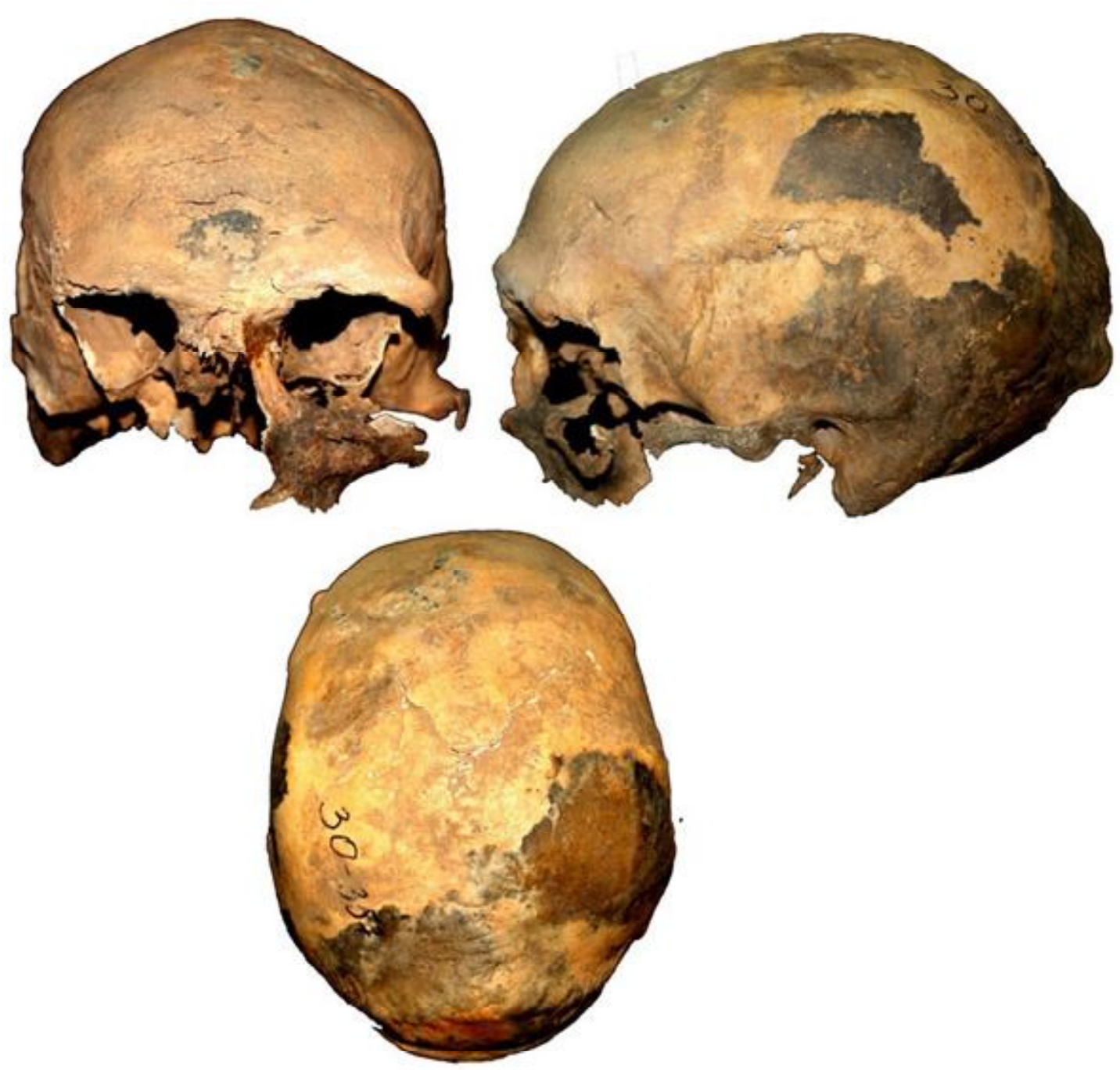

Рис. 5. Череп мужчины (35-45 лет) из погребения 1 кургана 51 могильника Перегрузное I

Fig. 5. Male skull (35-45 years old) from burial 1 of barrow 51 (Peregruznoe I burial mound) 
M.A. Balabanova. To the Anthropological Type of the Sarmatian Elite

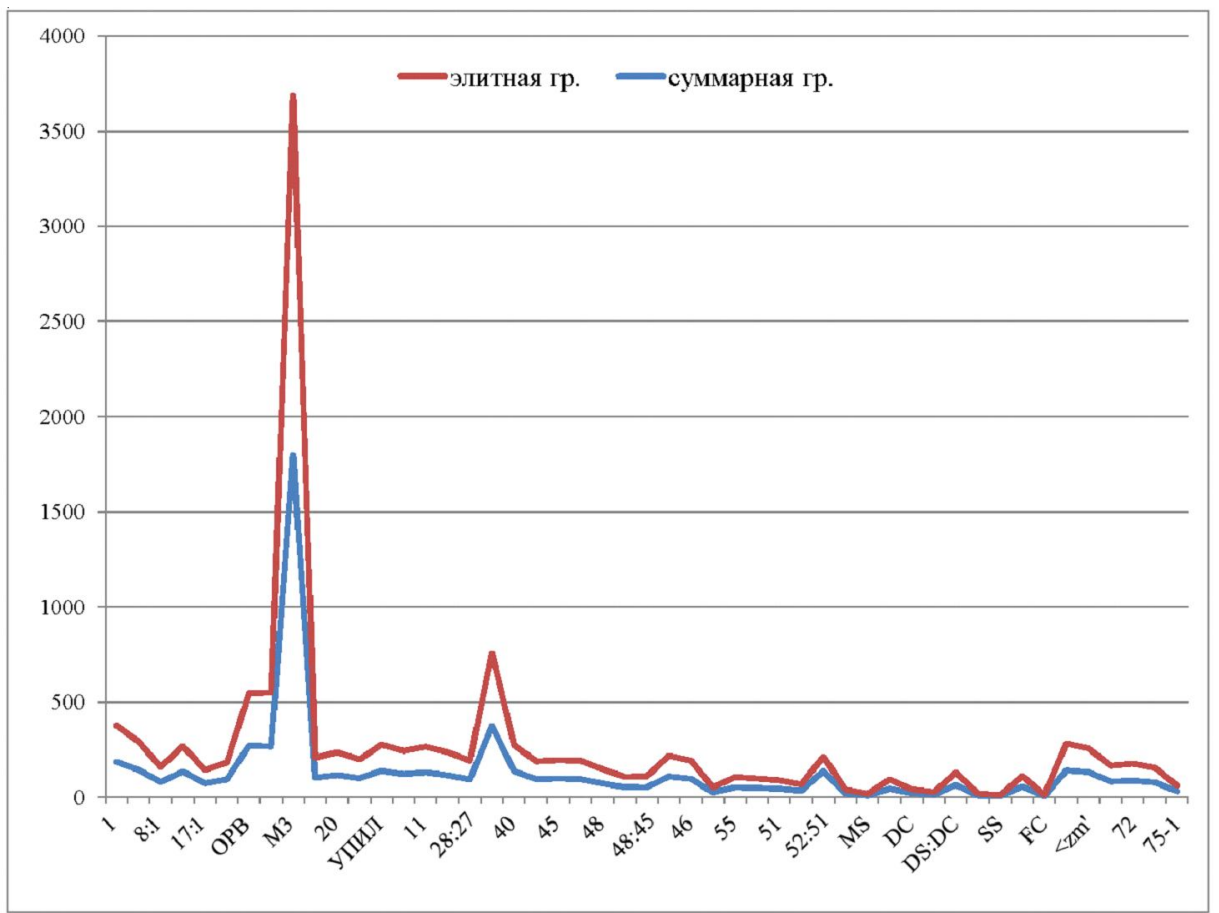

Рис. 6. Размах межгрупповой изменчивости по суммарной и элитной среднесарматским мужским группам, выраженный в средних значениях $(X)$

Fig. 6. The range of intergroup variability for total and elite average Sarmatian male groups, expressed in mean values $(X)$



Рис. 7. Размах межгрупповой изменчивости по суммарной и элитной среднесарматским мужским группам, выраженный в стандартных отклонениях $(s)$

Fig. 7. The range of intergroup variability for total and elite average Sarmatian male groups, expressed in standard deviations $(s)$ 
М.А. Балабанова. К антропологическому типу сарматской элиты

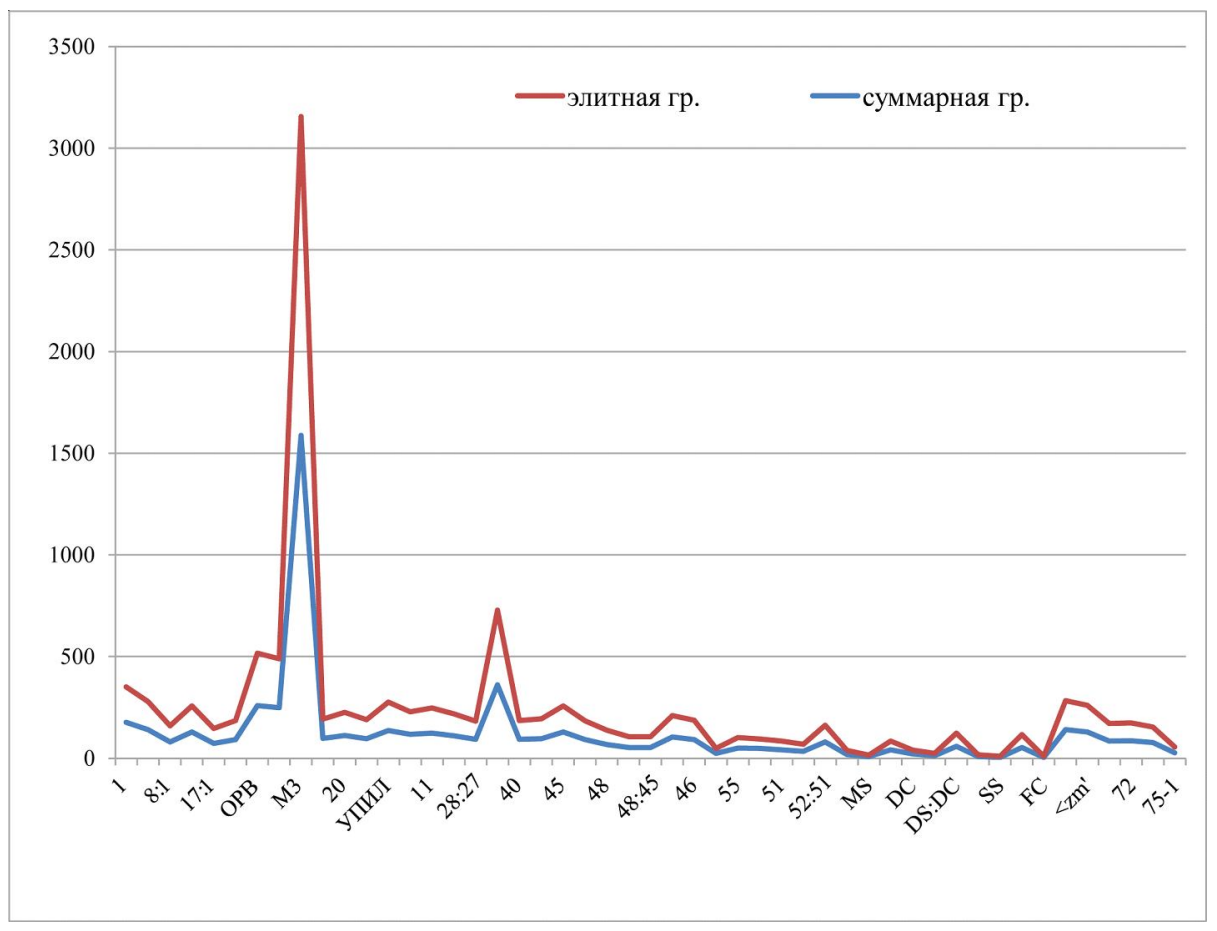

Рис. 8. Размах межгрупповой изменчивости по суммарной и элитной женским среднесарматским группам, выраженный в средних значениях $(X)$

Fig. 8. The range of intergroup variability for total and elite average Sarmatian female groups, expressed in mean values $(X)$



Рис. 9. Размах межгрупповой изменчивости по суммарной и элитной женским среднесарматским группам, выраженный в стандартных отклонениях $(s)$

Fig. 9. The range of intergroup variability for total and elite average Sarmatian female groups, expressed in standard deviations $(s)$ 


\section{ПРИМЕЧАНИЕ}

${ }^{1}$ Исследование выполнено при финансовой поддержке РФФИ и Администрации Волгоградской области, проект № 17-11-34009-ОГН «Элиты сарматского общества Волго-Донского региона (проблемы выделения и социальной интерпретации)».

\section{СПИСОК ЛИТЕРАТУРЫ}

Алексеев В. П., Дебец Г. Ф., 1964. Краниометрия. Методика антропологических исследований. М. : Наука. 127 с.

Балабанова М. А., Перерва Е. В., Клепиков В. М., Кривошеев М. В., Демкин В. А., Ельцов М. В., Скрипкин А. С., Удальцов С. Н., Яворская Л. В., Дьяченко А. Н., 2014. Курганный могильник Перегрузное I: результаты междисциплинарных исследований. Волгоград : Изд-во Волгогр. фил. ФГБОУ ВПО РАНХиГС. 360 с.

Балабанова М. А., Перерва Е. В., 2017. «Новое» и «старое» в антропологическом облике населения сарматского времени (по материалам погребений курганных групп Есауловского Аксая) // Материалы по археологии Волго-Донских степей. Вып. 4. Волгоград : Изд-во Волгогр. ин-та управления - филиала РАНХиГС. С. 114-201.

Батиева Е. Ф., 2000. Антропология погребения из 10 кургана Кобяковского могильника // Capматы и их соседи на Дону. Ростов н/Д: Терра. С. 95-99.

Беневоленская Ю. Д., 1980. Мировое распределение затылочно-теменного указателя // Современные проблемы и новые методы в антропологии. Л. : Наука. С. 70-90.

Беспалый Е. И., 1985. Курган I в. н.э. уг. Азова // Советская археология. № 4. С. 163-172.

Беспалый Е. И., 1992. Курган сарматского времени у г. Азова// Советская археология. № 1. С. 175-195.

Дворниченко В. В., Федоров-Давыдов Г. А., 1993. Сарматское погребение скептуха I в. н.э. у с. Косика Астраханской области // Вестник древней истории. № 3 (206). С. 141-179.

Засецкая И. П., 2011. Сокровища кургана Хохлач. Новочеркасский клад. СПб. : Изд-во Гос. Эрмитажа, 2011. 328 с.

Клейн Л. С., 1979. О характере римского импорта в богатых курганах сарматского времени на Дону // Античный мир и археология. Вып. 4. С. 204-211.

Клепиков В. М., 2013. Железные «жезлы» сарматских жриц // Шестая Международная Кубанская археологическая конференция : материалы конф. Краснодар: Экоинвест. 2013. С. 187-190.
Ковпаненко Г. Т., 1986. Сарматское погребение I в. н.э.: на Южном Буге. М. : Наукова думка. 152 с.

Козинцев А. Г., 1988. Этническая краниоскопия: расовая изменчивость швов черепа современного человека. Л. : Наука. 167 с.

Кривошеев М. В., 2016. Ножницы в погребальном обряде сарматов // Константин Федорович Смирнов и современные проблемы сарматской археологии : материалы IX Междунар. науч. конф. «Проблемы сарматской археологии и истории», посвящ. 100-летию со дня рождения Константина Федоровича Смирнова : сб. ст. Оренбург : Изд-во ОГПУ. С. 122-131.

Круц С. И., 1991. Антропологические материалы из сарматских погребений у с. Пороги // Симоненко А. В., Лобай Б. И. Сарматы СевероЗападного Причерноморья в I в. н.э. (погребения знати у с. Пороги). Киев : Наукова думка. С. 92-101.

Лукьяшко С. И., 2000. О семантике изображений на серебряном кувшине из кургана 28 группы Высочино VII // Нижневолжский археологический вестник. Вып. 3. С. 163-171.

Мордвинцева В. И., 1994. Серебряные фалары из Жутовского курганного могильника // Петербургский археологический вестник. № 8 . C. 96-100.

Мордвинцева В. И., 2013. Погребения варварских элит Северного Причерноморья на рубеже эр и их культурная идентичность // Античный мир и археология. Вып. 16. С. 329-339.

Перерва Е. В., 2012. Случай трепанации у сарматов (по антропологическим материалам из могильника Перегрузное I) // Вестник МГУ. Cер. XXIII: Антропология. № 2. С. 123-133.

Прохорова Т. А., Гугуев В. К., 1988. Богатое сарматское погребение в кургане на восточной окраине г. Ростова-на-Дону // Известия Ростовского областного музея краеведения. Вып. 5. С. 40-47.

Сергацков И. В., 2009. Сарматские погребения близ станции Бердия на Иловле // Археологические открытия. 1991-2004 гг. Европейская Россия. М. : Ин-т археологии РАН. С. 235-245.

Симоненко А. В., 2002. Латенский и римский импорт в сарматских погребениях Северного Причерноморья // Античная цивилизация и варварский мир : материалы 8-го археол. семинара. Краснодар, 13-15 июня 2001 г. Краснодар. С. 94-97.

Симоненко А. В., 2011. Римский импорт у сарматов Северного Причерноморья. СПб. : Филол. фак. СПбГУ : Нестор-История. 272 с.

Симоненко А. В., Лобай Б. И., 1991. Сарматы Северо-Западного Причерноморья в I в. н.э. (погребения знати у с. Пороги). Киев : Наукова думка. 112 с. 
Скрипкин А. С., 2017. Об элите среднесарматского общества по данным письменных источников и археологическим материалам Нижнего Поволжья // Нижневолжский археологический вестник. Т. 16. № 1. С. 5-18.

Скрипкин А. С., Мыськов Е. П., 2009. Погребение сарматской знати из Волгоградского Подонья // Археологические открытия. 1991-2004 гг. Европейская Россия. М. : Ин-т археологии PAH. C. 245-256.

Трейстер М. Ю., 2016. Кочевники на перекрестке трансевразийских караванных путей (западные импорты в сарматском погребении кургана № 21 могильника Магнитный) // К. Ф. Смирнов и современные проблемы сарматской археологии : материалы IX Междунар. науч. конф. «Проблемы сарматской археологии и истории», посвящ. 100-летию со дня рождения Константина Федоровича Смирнова, г. Оренбург, 11-16 мая 2016 г. Оренбург : Изд-во ОГПУ. C. 279-287.

Яценко С. А., 2016. Сарматская элита у границ Боспора I-III вв. н.э. // Элита Боспора и Боспорская элитарная культура : материалы Междунар. круглого стола (г. Санкт-Петербург, 2225 нояб.). СПб. : ПАЛАЦЦО. С. 276-282.

Demkin V. A., Klepikov V. M., Udaltsov S. N., Demkina T. S., Eltsov M. V., Khomutova T. E., 2014. New aspects of natural science studies of archaeological burial monuments (kurgans) in the southern Russian steppes // Journal of Archaeological Science. № 42. P. 241-249.

\section{REFERENCES}

Alekseev V.P., Debets G.F., 1964. Craniometry: Methods of Anthropological Research. Moscow, Nauka Publ. 127 p. (in Russian).

Balabanova M.A., Pererva E.V., Klepikov V.M., Krivosheev M.V., Demkin V.A., Eltsov M.V., Skripkin A.S., Udaltsov S.N., Yavorskaya L.V., Dyachenko A.N., 2014. Peregruznoe I Burial Mound: Results of the Interdisciplinary Research. Volgograd, Publishing House of Volgograd Branch RANKhiGS. 360 p. (in Russian).

Balabanova M.A., Pererva E.V., 2017. The New and the Old in the Anthropological Appearance of the Sarmatian Population (Based on the Burial Materials of the Barrow Groups of the Esaulovskiy Aksai). Materialy po arkheologii Volgo-Donskikh stepey. Iss. 4. Volgograd, Publishing House of Volgograd Branch of RANKHIGS, pp. 114-201. (in Russian).

Batieva E.F., 2000. Anthropology of the Burial from Barrow 10 of the Kobyakovskiy Burial Mound.
Sarmaty i ikh sosedi na Donu. Rostov-on-Don, Terra Publ., pp. 95-99. (in Russian).

Benevolenskaya Yu.D., 1980. World Distribution of the Occipital and Parietal Index. Sovremennye problemy $i$ novye metody $v$ antropologii. Leningrad, Nauka Publ., pp. 70-90. (in Russian).

Bespalyy E.I., 1985. Barrow of the $1^{\text {st }}$ Century AD near the City of Azov. Sovetskaya arkheologiya, no. 4, pp. 163-172. (in Russian).

Bespalyy E.I., 1992. A Sarmatian Barrow near the City of Azov. Sovetskaya arkheologiya, no. 1, pp. 175-195. (in Russian).

Dvornichenko V.V., Fedorov-Davydov G.A., 1993. The Sarmatian Burial of Skeptuch of the $1^{\text {st }}$ Century AD near the Village of Kosika of the Astrakhan Region. Journal of Ancient History, no. 3 (206), pp. 141-179. (in Russian).

Zasetskaya I.P., 2011. Treasures from the Khokhlach Barrow. Novocherkassk Hoard. Saint Petersburg, The State Hermitage Publ. 328 p. (in Russian).

Klein L.S., 1979. On the Nature of Roman Imports in Rich Barrows of the Sarmatian Time on the Don River. Antichnyy mir $i$ arkheologiya, iss. 4, pp. 204-211. (in Russian).

Klepikov V.M., 2013. Iron "Rods" of Sarmatian Priestesses. Shestaya Mezhdunarodnaya Kubanskaya arkheologicheskaya konferentsiya: materialy konf. Krasnodar, Ekoinvest Publ., pp. 187-190. (in Russian).

Kovpanenko G.T., 1986. Sarmatian Burial of the $1^{\text {st }}$ Century BC on the Southern Bug. Moscow, Naukova dumka Publ. 152 p. (in Russian).

Kozintsev A.G., 1988. Ethnic Cranioscopy: Racial Variability of Skull Seams of a Modern Man. Leningrad, Nauka Publ. 167 p. (in Russian).

Krivosheev M.V., 2016. Scissors in the Burial Rite of the Sarmatians. Konstantin Fedorovich Smirnov i sovremennye problemy sarmatskoy arkheologii: materialy IX Mezhdunar. nauch. konf. "Problemy sarmatskoy arkheologii $i$ istorii", posvyashchennoy 100-letiyu so dnya rozhdeniya Konstantina Fedorovicha Smirnova. Orenburg, Izd-vo OGPU, pp. 122-131.

Kruts S.I., 1991. Anthropological Materials from Sarmatian Burials near the Village of Porogi. Simonenko A.V., Lobai B.I. The Sarmatians and the North Pontic Area in the $1^{\text {st }}$ century AD (Noble Burials near the Village of Porogi). Kiev, Naukova dumka Publ., pp. 92-101. (in Russian).

Lukyashko S.I., 2000. About the Meaning of the Images Represented on the Jug of Silver Pitcher from Barrow 28 of the Vysochino-VII Group. The Lower Volga Archaeological Bulletin, iss. 3, pp. 163-171. (in Russian). 
Mordvintseva V.I., 1994. Silver Phalerae from the Dzutovskiy Burial Mound. Peterburgskiy arkheologicheskiy vestnik, no. 8, pp. 96-100. (in Russian).

Mordvintseva V.I., 2013. Graves of the Barbarian Elites of the North Pontic Region at the Turn of the Eras and Their Cultural Identity. Antichnyy mir i arkheologiya, iss, 16, pp. 329. 339. (in Russian).

Pererva E.V., 2012. The Case of Trepanation among the Sarmatians (Anthropological Materials from the Burial Mound Peregruznoe I). Vestnik Moskovskogo Universiteta. Seriya XXIII: Antropologiya, no. 2, pp. 123-133. (in Russian).

Prokhorova T. A., Guguev V. K., 1988. Rich Sarmatian Burial in the Barrow on the Eastern Outskirts of Rostov-on-Don. Izvestiya Rostovskogo oblastnogo muzeya kraevedeniya, iss. 5, pp. 4047. (in Russian)

Sergatskov I.V., 2009. Sarmatian Burials near the Station Berdia on the Ilovlya River. Arkheologicheskie otkrytiya. 1991-2004 gg. Evropeyskaya Rossiya. Moscow, IA RAN Publ., pp. 235-245. (in Russian).

Simonenko A.V., 2002. Latene and Roman imports in the Sarmatian Burials of the North Pontic Region. Antichnaya tsivilizatsiya $i$ varvarskiy mir: materialy 8-go arkheol. seminara (Krasnodar, 13-15 June 2001). Krasnodar, pp. 94-97. (in Russian).

Simonenko A.V., 2011 Roman Import for the Sarmatians of the North Pontic Region. Saint Petersburg, Nestor-Historia Publ. 272 p. (in Russian).
Simonenko A.V., Lobai B.I., 1991. The Sarmatians and the North Pontic Area in the $1^{\text {st }}$ century AD. Kiev, Naukova dumka Publ. 112 p. (in Russian).

Skripkin A.S., 2017. About the Elite of Middle Sarmatian Society Based on Archaeological Materials of the Lower Don Region. The Lower Volga Archaeological Bulletin, vol. 16, no. 1, pp. 518. (in Russian).

Skripkin A.S., Myskov E.P., 2009. The Burial of Sarmatian Nobility of the Volgograd's Don Region. Arkheologicheskie otkrytiya. 19912004 gg. Evropeyskaya Rossiya. Moscow, IA RAN Publ., pp. 245-256. (in Russian).

Treister M.Yu., 2016. The Nomads on the Crossroads of Trans-Eurasian Caravan Routes (Western Imports in Sarmatian Burial of Barrow 21 of the Magnitnyy Burial Mound). K.F. Smirnov $i$ sovremennye problemy sarmatskoy arkheologii: materialy IX Mezhdunar. nauch. konf. "Problemy sarmatskoy arkheologii $i$ istorii", posvyashch. 100-letiyu so dnya rozhdeniya Konstantina Fedorovicha Smirnova. Orenburg, Izd-vo OGPU, pp. 279-287. (in Russian).

Yatsenko S.A., 2016. Sarmatian Elite on Bosporus Borders in the $1^{\text {st }}-3^{\text {rd }}$ cc. AD. Elita Bospora $i$ Bosporskaya elitarnaya kultura: materialy Mezhdunar. kruglogo stola (Saint Petersburg, November 22-25, 2016). Saint Petersburg, PALACCO Publ., pp. 276-282 (in Russian).

Demkin V.A., Klepikov V.M., Udaltsov S.N., Demkina T.S., Eltsov M.V., Khomutova T.E., 2014. New aspects of natural science studies of archaeological burial monuments (kurgans) in the southern Russian steppes. Journal of Archaeological Science, no. 42, pp. 241-249.

\section{Information about the Author}

Mariya A. Balabanova, Doctor of Sciences (History), Professor of Department of Russian and Foreign History, Archaeology, Volgograd State University, Prosp. Universitetsky, 100, 400062 Volgograd, RussianFederation, mary_balabanova@mail.ru,mary.balabanova@volsu.ru, adsi@volsu.ru.

\section{Информация об авторе}

Мария Афанасьевна Балабанова, доктор исторических наук, профессор кафедры отечественной и зарубежной истории, Волгоградский государственный университет, просп. Университетский, 100, 400062 г. Волгоград, Российская Федерация, mary_balabanova@mail.ru, mary.balabanova@volsu.ru, adsi@volsu.ru. 